Gelanggang Olahraga: Jurnal Pendidikan Jasmani dan Olahraga

Volume 2, Nomor 2, Januari-Juni 2019

e-ISSN : 2597-6567

p-ISSN : 2614-607X

DOI : https://doi.org/10.31539/jpjo.v2i2.742

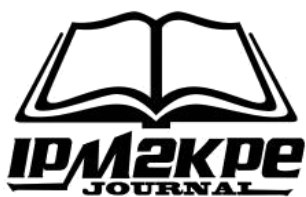

\title{
TINJAU KONDISI FISIK WASIT SEPAK BOLA PSSI SUMATERA SELATAN
}

\author{
Azizil Fikri ${ }^{1}$, Popalri ${ }^{2}$ \\ STKIP-PGRI Lubuklinggau ${ }^{1,2}$ \\ azil_azizil@yahoo.com ${ }^{1}$
}

\begin{abstract}
ABSTRAK
Penelitian ini bertujuan untuk meninjau kondisi fisik wasit sepakbola PSSI Sumatera Selatan. Jenis penelitian ini bersifat deskriptif. Sampel menggunakan teknik total sampling. maka sampel sebanyak 36 orang. Jenis data yaitu data primer dan sekunder. Teknik pengumpulan data dalam penelitian ini adalah Tes Kecepatan lari $6 \times 40$ meter dengan waktu rata-rata 6,2 detik, diikuti dengan recovery waktu 90 detik kembali ketempat star dan juga tes daya tahan lari $20 \mathrm{x}$ 150 meter dengan waktu rata-rata 30 detik, diikuti dengan recovery selama 50 detik untuk berjalan sepanjang 50 meter menuju ke star yang kedua dan seterusnya. Berdasarkan analisis data, daya tahan wasit CIII berada pada kategori cukup dengan rata-rata 13, artinya wasit CIII hanya mampu melakukan 7 kali pengulangan dalam melakukan lari satu lintasan lapangan. Wasit CII berada pada kategori kurang dengan rata-rata 10, ini artinya bahwa wasit CII hanya mampu melakukan 5 kali pengulangan dalam melakukan lari satu lintasan lapangan. Selanjutnya wasit CI berada pada kategoribaik dengan rata-rata 15, artinya bahwa wasit CI hanya mampu melakukan 5 kali pengulangan dalam melakukan lari satu lintasan lapangan. Kemampuan kondisi fisik wasit sepakbola PSSI Sumatera Selatan berdasarkan tes daya tahan berada pada taraf baik. Wasit CIII dilihat dari segi kecepatan berada pada ketegori baik sekali dengan rata-rata 5, selanjutnya wasit CII berada pada ketegori baik, dan wasit CI berada pada ketegori baik sekali. Simpulan, kondisi fisik wasit sepakbola PSSI Sumatera Selatan berada pada kategori baik sekali.
\end{abstract}

Kata Kunci: Kondisi Fisik, Wasit, Sepak Bola

\begin{abstract}
This study aims to review the physical condition of the football referee PSSI South Sumatra. This type of research is descriptive. The sample uses total sampling technique. then the sample is 36 people. Data types are primary and secondary data. The data collection technique in this study was a running speed test of $6 x$ 40 meters with an average time of 6.2 seconds, followed by recovery time of 90 seconds back to the star and also a durability test running $20 \times 150$ meters with an average time of 30 seconds, followed by recovery for 50 seconds to walk 50 meters to the second star and so on. Based on data analysis, referee CIII resilience is in a sufficient category with an average of 13, meaning that referee CIII is only able to do 7 repetitions in running a field track. Referee CII is in the less category with an average of 10, this means that the CII referee is only able to
\end{abstract}


do 5 repetitions in a single track run. Furthermore, the CI referee is in the best category with an average of 15, meaning that the CI referee is only able to do 5 repetitions in a single track run. The ability of the soccer referee PSSI South Sumatra's physical condition based on endurance tests is at a good level. Wit CIII seen in terms of speed is in the category very well with an average of 5, then the referee CII is in good category, and the referee CI is in excellent category. Conclusion, the physical condition of the football referee PSSI South Sumatra is in a very good category.

Keywords: Physical Condition, Referee, Football

\section{PENDAHULUAN}

Olahraga merupakan kegiatan yang dibutuhkan setiap orang, dengan berolahraga orang mendapatkan kesegaran jasmani, kesegaran pemikiran dan berprestasi dalam pekerjaan, sehingga dapat meningkatkan produktifitas kerja. Di sisi lain olahraga juga dijadikan ajang kompetisi dalam penyampaian sebuah prestasi, sebagai wujud mempertahankan prestasi baik individu, kelompok maupun negeri asal. Undang-undang Nomor. 3 Tahun 2005 pasal 1 ayat 4 disebutkan "olahraga adalah segala kegiatan yang sistematis untuk mendorong, membina serta mengembangkan potensi jasmani, rohani dan sosial".

Banyak sekali faktor-faktor yang mempengaruhi perkembangan sepakbola, diantaranya pelatih, sarana dan prasarana, sumber daya manusia dalam hal ini pemain atau atlet, dan yang memimpin suatu pertandingan yakni Wasit. Pada saat sekarang daerah Sumatera Selatan terjadi perkembangan sepakbola yang sangat pesat dan telah banyak memiliki Wasit yang bersertifikat, namun tidak hanya dengan memiliki sertifikat saja, seorang Wasit dikatakan mampu memimpin suatu pertandingan dengan baik karena dalam mengambil suatu keputusan seorang Wasit harus memiliki kondisi fisik yang bagus. Kondisi fisik (physical conditioning) selain berguna untuk meningkatkan kesegaran jasmani, kondisi fisik merupakan program pokok dalam pembinaan pemain untuk berprestasi dalam suatau cabang olahraga.

Dalam suatu pertandingan sepakbola, sedikit saja Wasit lalai dalam mengambil keputusan dapat mengakibatkan kerugian bagi salah satu tim yang bertanding, diantaranya disebabkan karena jauhnya seorang Wasit dari pada bola, sehingga dalam memimpin pertandingan tidak dapat menguasai jalannya pertandingan dan salah dalam mengambil keputusan, maka dari itu seorang Wasit harus memiliki kondisi fisik yang bagus dalam memimpin pertandingan sepakbola sesuai dengan tes kondisi fisik dan kebugaran seorang wasit sepakbola yang keluarkan oleh FIFA. Untuk mengurangi tingkat kesalahan mengambil keputusan dalam pertandingan maka proses latihan di arahkan kepada pembinaan kondisi fisik, khususnya daya tahan dan kecepatan. Sebab faktor-faktor inilah yang sangat dominan dalam memimpim suatu pertandingan sepakbola sehingga menjadi sukses.

Berdasarkan uraian diatas dapat disimpulkan bahwa tanpa adanya latihan fisik, maka kemampuan fisik seorang Wasit yang diharapkan akan sulit dicapai. Karena tanpa kondisi fisik yang bagus maka seorang Wasit akan cepat mengalami kelelahan sehingga dalam mengambil keputusan tidak tepat lagi pada peraturan yang sesungguhnya. 
Pada Wasit sepakbola Sumatera Selatan belum adanya pihak yang mendata tentang kemampuan kondisi fisik Wasit, hal ini terlihat dari setiap digelarnya turnamen sepakbola sering terjadi kesalahan dalam mengambil keputusan sehingga menuai protes. Kurangnya kemampuan fisik Wasit sepakbola Asprov PSSI Sumatera Selatan diduga karena rendahnya tingkat latihan kondisi fisik khususnya pada aspek daya tahan dan kecepatan yang dimiliki oleh Wasit sepakbola. Hal tersebut terlihat pada saat memimpin suatu pertandingan, pada babak pertama Wasit dapat menguasai jalannya permainan dan dapat memperkecil tingkat kesalahan dalam mengambil keputusan.Namun pada babak kedua sudah tampak gejala menurunnya kondisi fisik Wasit, sehingga tidak dapat lagi menempatkan jarak dengan bola yang mengakibatkan terjadinya kesalahan dalam mengambil keputusan.

Kalau hal ini dibiarkan maka kemampuan kondisi fisik Wasit sepakbola Asprov PSSI Sumatera Selatan sulit untuk mencapai hasil yang maksimal di tingkat Provinsi maupun Nasional. Maka dari itu perlu dilakukan penelitian yang berhubungan dengan kemampuan kondisi fisik para Wasit sepakbola Sumatera Selatan. Oleh karena itu, perlu dikaji faktor-faktor yang menyebabkan lemahnya kondisi fisik Wasit sepakbola Asprov PSSI Sumatera Selatan dalam memimpin suatu pertandingan, sehingga penelitian ini bisa menghasilkan suatu kesimpulan yang bisa menjadi langkah antisipasi dan evaluasi bagi kemajuan Wasit sepak bola ke depan.

\section{KAJIAN TEORI Kondisi Fisik}

Untuk terwujudnya kesuksesan dalam memimpin pertandingan sepakbola, kondisi fisik Wasit sepakbola yang baik merupakan suatu hal yang sangat diperlukan, Jonath Krempel dalam Syafrudin (1999), mengatakan kondisi fisik itu dibedakan atas pengertian sempit dan luas. Dalam arti sempit kondisi fisik merupakan keadaan yang meliputi factor kekuatan, kecepatan dan daya tahan.Sedangkan dalam arti luas adalah ketiga faktor kekuatan, kecepatan dan daya tahan ditambah dengan faktor kelenturan (fleksibility) dan koordinasi (coordination). Sarumpaet (1986) mengatakan, kondisi fisik adalah keadaan fisik seseorang pada saat tertentu untuk melakukan suatu pekerjaan yang dijadikan bebannya. Seseorang dapat dikatakan berada dalam kondisi fisik baik kalau ia mampu melakukan pekerjaan yang dibebankan kepadanya atau yang ingin dilakukannya tanpa kelelahan yang berlebihan.

Sementara itu Prihastono, (1999) berpendapat komponen kondisi fisik terdiri atas 2 bagian yaitu : pertama, kondisi fisik umum adalah kemampuan dasar untuk mengembangkan kemampuan tubuh yang terdiri dari : kekuatan, daya tahan, kecepatan, kelenturan, dan kelincahan. Selanjutnya Frohner dalam Syafruddin (1999) bahwa latihan kondisi fisik umum berarti latihan-latihan yang beraneka ragam untuk mengembangkan kemampuan tubuh dan merupakan dasar untuk meningkatkan kemampuan kondisi fisik khusus. Sedangkan kemampuan kondisi fisik khusus merupakan kemampuan yang langsung dikaitkan dengan kebutuhan masing-masing cabang olahraga. Jonath dan Krempel dalam Syafrudin (1999) mengatakan bahwa bila kondisi dihubungkan dengan kemampuan prestasi dalam suatu cabang olahraga tertentu, maka kondisi disini disebut degan kondisi fisik khusus. 


\section{Daya Tahan (endurance)}

Daya tahan secara umum menunjukan kemampuan menahan kelelahan dari organ-organ tubuh manusia daya tahan terutama tergantung dari jumlah otot yang dipergunakan. Sedangkan aktifitas gerakan yang mempergunakan lebih besar dari jumlah otot-otot yang dibebani disebut dengan "daya tahan umum" dan jika daya tahan itu berlangsung di bawah pemakaian Oksigen $\left(\mathrm{O}_{2}\right)$ dinamakan "aerobik", dan sebaliknya jika aktifitas itu berlangsung tanpa menggunakan oksigen (O2) dinamakan dengan "anerobik", Hos (1989). Tujuan utama dari latihan daya tahan adalah meningkatkan kemampuan kerja jantung disamping meningkatkan kerja paru-paru dan sistem peredaran darah. Selanjutnya (Darwis, 1999) mengemukakan "daya tahan adalah kemampuan organisme seseorang untuk mengatasi kelelahan yang timbul setelah melakukan aktifitas tubuh berolahraga dalam waktu lama".

Menurut Bompa dalam Arsil (1989), mengklasifikasikan daya tahan atas "daya tahan umum dan daya tahan khusus". Daya tahan umum adalah kemampuan sekelompok otot, sistem syaraf pusat, jantung dan pernafasan atau cardiorespiratory. Daya tahan menyangkut karekteristik setiap cabang olahraga. Sedangkan daya tahan lokal mengandung daya tahan otot, (Lamb, dalam Arsil. 1999). Daya tahan umum dikenal sebagai daya tahan jantung dan paru dan akan melibatkan aktivitas otot-otot yang luas, serta diarahkan pada daya tahan jantung dan pernafasan yang lazim disebut daya tahan cardiovaskuler. Sedangkan yang dimaksud dengan latihan daya tahan selanjutnya disebut endurance adalah latihan yang bertujuan untuk meningkatkan kemampuan seluruh tubuh untuk selalu bergerak dalam tempo sedang sampai cepat, dengan waktu yang cukup lama. Sedangkan yang dimaksud dengan endurance adalah kemampuan seseorang melaksanakan gerak dengan seluruh tubuhnya dalam waktu yang cukup lama dan dengan waktu sedang sampai cepat, tanpa mengalami rasa sakit dan kelelahan berat.

Ada sejumlah metode atau cara latihan untuk meningkatkan kapasitas daya tahan atau Endurance, mulai dari latihan interval training sampai latihan-latihan jarak jauh dalam tempo rendah. Pada dasarnya latihan lari, sepeda, dan berenang adalah merupakan latihan Endurance. Daya tahan yang dibutuhkan oleh seorang Wasit adalah daya tahan aerobik, karena Wasit akan memimpin pertandingan selama 2 x 45 menit, tidak saja Wasit dituntut untuk berlari terus menerus tetapi juga membutuhkan kecepatan yang dibutuhkan pada saat yang tiba-tiba.

\section{Kecepatan ( Speed)}

Kecepatan adalah kemampuan seseorang dalam melakukan gerakan yang berkesinambungan dalam bentuk yang sama dalam waktu yang sesingkatsingkatnya. Kata "cepat" berkaitan dengan 3 elemen, yaitu: waktu bereaksi (reaksi penggerak terhadap tanda), waktu gerak (kemampuan untuk menggerakkan otot dengan cepat, seperti pada latihan kemiliteran, memukul atau mengoper bola) dan kecepatan lari (termasuk frekuensi pergerakan tangan dan kaki).

Kecepatan reaksi menunjukan kemampuan untuk menjawab secepat mungkin suatu rangsangan melalui pendengaran, penglihatan dan rasa. Kecepatan asiklis ditandai oleh kecepatan reaksi maksimal melalui explosif dari otot. Kecepatan gerakan siklis sering juga digambarkan sebagai gerakan yang berulangulang, dimana gerakan ini dapat dikenal melalui kontraksi submaximal. Kontraksi 
submaximal adalah hasil dari amplitudo gerakan dengan frekruensi gerak .(Hos; 1989).

Jonath dan krempel dalam Syafruddin (1999) mengatakan "kecepatan dibatasi oleh faktor-faktor seperti; Kekuatan, Kecepatan dan koordinasi. Pada seorang Wasit sepakbola yang memiliki kecepatan yang baik akan mampu berada saat terjadinya pelanggaran atau kejadian-kejadian dalam pertandingan sepakbola, sehingga dapat mengambilkan keputusan yang adil seperti yang terdapat pada peraturan permainan pasal 12 peraturan umum pertandingan sepakbola.

\section{Wasit Sepakbola}

Wasit adalah seseorang yang memimpin dalam suatu pertandingan dan juga termasuk kedalam perangkat suatu pertandingan sepakbola, tanpa adanya Wasit yang memimpin dalam suatu pertandingan sepakbola maka pertandingan tersebut tidak akan bisa berlangsung. Sesuai dengan Pedoman Dasar PSSI menjadi seorang Wasit dapat diklasifikasikan sebagai berikut : C III Tingkat PENGCAB, C II Tingkat PENGDA, C I Tingkat Nasional dan FIFA Tingkat Internasional.

Untuk mencapai prestasi ke tingkat Internasional Wasit FIFA, sertifikasi yang harus diikuti terlebih dahulu yaitu: mengikuti penataran Khursus Wasit C III Tingkat Pengcab yang diselenggarakan oleh masing-masing Pengcab, selanjutnya mengikuti penataran khursus Wasit C II tingkat Pengda, yang diselenggarakan oleh Pengda di seluruh tanah air, dengan persyaratan antara lain: telah memiliki sertifikasi C III dan telah mengabdi minimal 2 tahun dengan usia dibawah 35 tahun, begitu juga dengan mengikuti penataran Wasit $\mathrm{C}$ I tingkat Nasional dengan persyaratan antara lain: telah memiliki sertifikasi Wasit C II dan mengabdi sekurangnya 2 tahun dengan usia tidak boleh lebih dari 35 tahun dengan ketentuan lulus mengikuti tes tertulis pemahaman peraturan permainan sepakbola dan tes kondisi fisik yang dikeluarkan oleh PSSI, seperti daya tahan dan kecepatan.

Dalam permainan sepakbola kategori usia pemain dapat dibedakan bermacam-macam, pembinaan pemain amatir PSSI mengenal klasifikasi pemain dalam kelompok usia, dibawah usia 14 tahun yang lama permainannya adalah $2 \mathrm{x}$ 20 menit, di bawah usia 16 tahun lamanya permainan adalah 2 x 30 menit di bawah usia 19 tahun lama permainan adalah 2 x 40 menit, dan di bawah usia 23 tahun lama permainan adalah 2 x 45 menit, (Peraturan permainan sepakbola PSSI).

Dari bermacam-macam perbedaan usia dan lamanya waktu pertandingan, maka seorang Wasit harus mampu untuk menyesuaikan diri dengan kebutuhankebutuhan yang mendukung akan kelancaran suatu pertandingan tersebut. Wasit haruslah memiliki kondisi fisik yang bagus, karena itu akan mempengaruhi terhadap hasil keputusan Wasit. Adapun beberapa tugas dan kekuasaan seorang Wasit adalah memimpin pertandingan bekerja sama dengan asisten Wasit, menegakkan peraturan permainan, memastikan bahwa setiap bola yang dipergunakan dalam bertanding telah memenuhi persyaratan yang ditentukan, memastikan perlengkapan pemain telah memenuhi persyaratan yang telah ditentukan, bertindak sebagai pencatat waktu dan mencatat hasil pertandingan, membuat keputusan untuk menghentikan, menunda atau mengakhiri pertandingan, menghentikan permainan apabila seoarng pemain mengalami cedera, memberikan hukuman atau tindakan disiplin terhadap pelanggaran yang 
dilakukan oleh pemain berupa kartu kuning dan kartu merah, memberikan tindakan terhadap official tim yang bertindak dengan cara-cara yang tidak bertanggung jawab, melarang orang yang tidak berkepentingan masuk kedalam lapangan permainan, memulai kembali pertandingan setelah dihentikan, membuat laporan pertandingan atas kejadian yang dialami pada saat memimpin pertandingan dan menyerahkannya kepada pihak yang berwenang. Adapun keputusan Wasit mengenai fakta-fakta yang berkaitan dengan permainan adalah mutlak (final). Begitu juga dengan tugas asisten Wasit antara lain: memberikan isyarat apabila keseluruhan bagian bola telah keluar dari lapangan permainan, mengisyaratkan pihak mana yang berhak untuk suatu tendangan sudut, tendangan gawang atau lemparan kedalam, mengisyaratkan bahwa pemain dapat dihukum karena berada dalam posisi offside, memberikan isyarat apabila ada pergantian pemain, memberikan isyarat apabila terjadi pelanggaran atau insiden yang tidak terlihat ketika itu asisten Wasit berada lebih dekat dari kejadian dari pada Wasit.

Melihat dari tugas dan kekuasaan Wasit dan asisten wasit yang telah diuraikan di atas, tidak mungkin rasanya seorang Wasit dan asisten wasit akan memimpin pertandingan secara adil dan bijaksana tanpa diiringi oleh kondisi fisik yang bagus sehingga dapat memperkecil kesalahan dalam pertandingan.

\section{METODE PENELITIAN}

Jenis penelitian ini bersifat deskriptif, peneliti hanya melihat bagaimana kemampuan kondisi fisik wasit sepakbola PSSI Sumatera Selatan. Penelitian ini dilaksanakan di Trek Atletik lapangan Gelora Sriwijaya Palembang, antara bulan April - Juni 2019. Populasi penelitian ini adalah Wasit-wasit yang terdaftar sebagai anggota wasit PSSI Sumatera Selatan yang terdiri dari wasit C I, C II dan C III, yang berjumlah 36 orang (Sumber data: Data Pengurus PSSI Sumatera Selatan tahun 2019). Berpedoman kepada populasi maka sampel yang diambil menggunakan teknik total sampling, yakni semua populasi dijadikan sampel yaitu sebanyak 36 orang.

Jenis data penelitian yang diambil dalam suatu penelitian yaitu: data primer (data yang diambil langsung melalui tes kondisi fisik wasit sepakbola PSSI Sumatera Selatan) dan sekunder (data yang diambil dari pengurus PSSI Sumatera Selatan). Data yang diperoleh dalam penelitian ini diambil langsung dari Wasit PSSI Sumatera Selatan.

Teknik pengumpulan data dalam penelitian ini adalah Tes Kecepatan lari 6 x 40 meter dengan waktu rata-rata 6,2 detik, diikuti dengan recovery waktu 90 detik kembali ketempat star. Dan juga tes Daya Tahan lari $20 \times 150$ meter dengan waktu rata-rata 30 detik, diikuti dengan recovery selama 50 detik untuk berjalan sepanjang 50 meter menuju ke star yang kedua dan seterusnya. (kedua tes di atas berdasarkan petunjuk Tes Kesehatan/Kebugaran Wasit FIFA/AFC/PSSI).

Instrumen penelitian ini yakni peserta berdiri di belakang garis star, dengan sikap star berdiri. Pada saat bendera diangkat oleh starter peserta berusaha lari secepat mungkin mencapai garis finis, kemudian berjalan kembali ke garis star diikuti dengan pemulihan 1,5 menit/ 90 detik. Tiap Peserta melakukan 6 kali pengulangan dengan jarak tempuh 40 meter.

Setiap peserta sebelum peluit berbunyi mesti sampai di area jalan atau posisi star 1 dan star 2, peserta bersiap-siap dengan mengambil posisi star berdiri, sewaktu peluit dibunyikan dan bendera diangkat oleh sterter para peserta memulai 
lari sampai kepada finish yang telah ditentukan dengan jarak tempuh 150 meter dan starter mencatat waktu peserta yang masuk pada garis finish, sampai pada garis finish peserta melakukan pemulihan dengan cara berjalan menuju garis star yang kedua dengan jarak tempuh 50 meter dan waktu 50 detik. Pada peluit berikutnya para peserta berlari kembali sepanjang 150 meter dengan waktu 30 detik dan diikuti dengan recovery sambil berjalan sepanjang 50 meter dengan jangka waktu 50 detik kembali. Seluruh rangkaian ini sama dengan 1 lap/keliling. Jumlah minimum yang harus dicapai adalah sebanyak 10 lap.Para peserta berlari dalam grup-grup kecil dengan jumlah masksimal 6 orang pada setiap starnya.

Setelah hasil data dilapangan dikumpulkan selanjutnya dilakukan pengelolaan data berdasarkan data yang terkumpul dan telah memenuhi syarat untuk dianalisa, teknik analisa data dilakukan dengan menggunakan deskriptif yang menggunakan tabulasi frekruensi dan rata-rata dan dibantu dengan program komputer SPSS V.12 dengan rumus sebagai berikut :

$$
\mathrm{P}=\frac{\mathrm{F}}{\mathrm{N}} \times 100 \%
$$

Keterangan :

$$
\begin{aligned}
& \mathrm{P}=\text { Persentase } \\
& \mathrm{F}=\text { Frekruensi } \\
& \mathrm{N}=\text { Jumlah Sampel }
\end{aligned}
$$

\section{HASIL PENELITIAN}

\section{Kondisi Fisik Wasit Sepakbola PSSI Sumatera Selatan Dilihat dari Segi Daya Tahan lari 20 x 150 Meter}

Data kondisi fisik wasit sepakbola PSSI Sumatera Selatan yang diperoleh dari studi langsung kepada 36 orang wasit sepakbola PSSI Sumatera Selatan, dalam pembahasan ini akan di bagi dalam tingkatan wasit menurut kualifikasi wasit yang terdiri dari CIII tingkat PENGCAP, CII PENGDA dan CI NASIONAL. Dalam penilaian hasil pengukuran yang dilakukan terhadap 12 orang wasit CIII tingkat PENGCAP diperoleh skor tertinggi 20, skor terendah 11, mean sebesar 13,91, median sebesar 13,5, modus sebesar 13, dan simpangan baku sebesar 2,66. Untuk lebih jelasnya deskripsi data kondisi fisik wasit sepakbola PSSI Sumatera Selatan kualifikasi CIII dilihat dari daya tahan lari 20 x 150 meter. Kondisi fisik wasit CIII yang dijadikan sampel di dalam penelitian ini, terbanyak berada pada skor nilai 12.5-14.4.

Selanjutnya hasil pengukuran yang dilakukan terhadap 14 orang wasit CII tingkat Asprov diperoleh skor tertinggi 18, skor terendah 11, mean sebesar 12,57, median sebesar 12, modus sebesar 12, dan simpangan baku sebesar 2,02. Untuk lebih jelasnya deskripsi data kondisi fisik wasit sepakbola PSSI Sumatera Selatan kualifikasi CII dilihat dari daya tahan lari 20 x 150 meter. Kondisi fisik wasit CII yang dijadikan sampel di dalam penelitian ini, terbanyak berada pada skor nilai 10.5-12.4.

Selanjutnya hasil pengukuran yang dilakukan terhadap 10 orang wasit CI tingkat Nasional diperoleh skor tertinggi 20, skor terendah 11, mean sebesar 15.1, median sebesar 14.5, modus sebesar 16, Dan simpangan baku sebesar 3.03. Untuk lebih jelasnya deskripsi data kondisi fisik wasit sepakbola PSSI Sumatera Selatan kualifikasi CI dilihat dari daya tahan lari 20 x 150 meter. Kondisi fisik wasit CI 
yang dijadikan sampel di dalam penelitian ini, terbanyak berada pada skor nilai 14.5-16.4 dan 12.5-14.

\section{Kondisi Fisik Wasit Sepakbola PSSI Sumatera Selatan Dilihat dari Segi Kecepatan Lari 6 x 40 meter}

Data kondisi fisik wasit sepakbola PSSI Sumatera Selatan yang diperoleh dari studi langsung kepada 36 orang wasit sepakbola PSSI Sumatera Selatan, dalam pembahasan ini akan di bagi dalam tingkatan wasit menurut kualifikasi wasit yang terdiri dari CIII tingkat PENGCAP, CII PENGDA dan CI NASIONAL. Dalam penilaian hasil pengukuran yang dilakukan terhadap 12 orang wasit CIII tingkat PENGCAB diperoleh skor tertinggi 6, skor terendah 2, mean sebesar 3,91, median sebesar 4, modus sebesar 5, dan simpangan baku sebesar 1,37. Untuk lebih jelasnya deskripsi data kondisi fisik wasit sepakbola PSSI Sumatera Selatan kualifikasi CIII dilihat dari kecepatan lari 6 x 40 meter. Kondisi fisik wasit CIII yang dijadikan sampel di dalam penelitian ini, terbanyak berada pada skor nilai 4.5 - 5.4. 4 orang (33\%) wasit C III Tingkat Pengcap dari segi daya tahan lari $20 \times 150$ Meter dengan waktu 30 detik recovery 50 detik berada pada ketegori baik sekali, 1 orang $(8 \%)$ berada pada ketegori superior, 3 orang $(25 \%)$ berada pada ketegori baik, 1 orang $(8 \%)$ berada pada ketegori cukup dan 3 orang $(25 \%)$ berada pada ketegori kurang. Jadi berdasarkan klasifikasi di atas dapat dinyatakan bahwa wasit C III Tingkat Pengcap dari segi daya tahan lari $20 \times 150$ Meter berada pada ketegori baik sekali dengan rata-rata 4 dan persentase $33 \%$.

Dalam penilaian hasil pengukuran yang dilakukan terhadap 14 orang wasit CII tingkat Pengda diperoleh skor tertinggi 6, skor terendah 1, mean sebesar 4,14, median sebesar 4, modus sebesar 4, Dan simpangan baku sebesar 1,51. Untuk lebih jelasnya deskripsi data kondisi fisik wasit sepakbola PSSI Sumatera Selatankualifikasi CII dilihat dari kecepatan lari 6 x 40 meter. Kondisi fisik wasit CII yang dijadikan sampel di dalam penelitian ini, terbanyak berada pada skor nilai 3.5 - 4.4. 3 orang (21\%) wasit C II Pengda dari segi daya tahan lari $20 \times 150$ Meter dengan waktu 30 detik recovery 50 detik berada pada ketegori baik sekali, 3 orang (21\%) barada pada ketegori superior, 4 orang (29\%) barada pada ketegori baik, 2 orang (14\%) barada pada ketegori cukup dan 2 orang (14\%) barada pada ketegori kurang. Jadi berdasarkan klasifikasi di atas dapat dinyatakan bahwa wasit C II Pengda dari segi daya tahan lari 20 x 150 Meter berada pada ketegori baik sekali dengan rata-rata 4.1 dan persentase $29 \%$.

Dalam penilaian hasil pengukuran yang dilakukan terhadap 10 orang wasit CI tingkat Nasional diperoleh skor tertinggi 6, skor terendah 1, mean sebesar 4,6, median sebesar 5, modus sebesar 5, Dan simpangan baku sebesar 1,42. Untuk lebih jelasnya deskripsi data kondisi fisik wasit sepakbola PSSI Sumatera Selatan kualifikasi CI dilihat dari kecepatan lari 6 x 40 meter. Kondisi fisik wasit CI yang dijadikan sampel di dalam penelitian ini, terbanyak berada pada skor nilai 4.5 5.4. 5 orang $(50 \%)$ wasit C I Nasional dari segi daya tahan lari $20 \times 150$ Meter dengan waktu 30 detik recovery 50 detik berada pada ketegori baik sekali, 2 orang (20\%) barada pada ketegori superior, 2 orang (20\%) barada pada ketegori baik, dan 1 orang (10\%) barada pada ketegori kurang. Jadi berdasarkan klasifikasi di atas dapat dinyatakan bahwa wasit C I Nasional dari segi daya tahan lari 20 x 150 Meter berada pada ketegori baik sekali dengan rata-rata 4.5 dan persentase $50 \%$. 


\section{Uji normalitas data}

Analisis uji normalitas dalam penelitian bertujuan untuk menguji asumsi bahwa distribusi sampel dari data sampel mendekati normalitas populasi. Pengujian normalitas penyebaran skor data dengan menggunakan Uji ShapiroWilk. Taraf signifikansi yang digunakan sebagai dasar menolak atau menerima keputusan normal/tidaknya suatu distribusi data adalah :

\section{Wasit CIII Tingkat Pengcap Daya tahan lari 20 x 150 Meter.} bawah ini:

Hasil perhitungan uji normalitas dapat dilihat pada lampiran dan seperti di

Tabel 1

Uji Normalitas

\begin{tabular}{llllllll}
\hline & \multicolumn{3}{c}{ Kolmogorov-Smirnov(a) } & \multicolumn{3}{c}{ Shapiro-Wilk } \\
\cline { 2 - 7 } Daya tahan wasit CIII & Statistic & df & Sig. & Statistic & df & Sig. \\
\cline { 2 - 8 } & .155 & 12 & $.200^{*}$ & .894 & 12 & .133 \\
\hline
\end{tabular}

a. Lilliefors Significance Correction

Dari tabel 1, dapat dilihat skor Signifikansi untuk kondisi fisik Wasit CIII PSSI Sumatera Selatan dilihat dari segi daya tahan sebesar 0.894. Berdasarkan landasan pengambilan keputusan di atas, Ha diterima. Dengan demikian dapat dinyatakan bahwa data dari kondisi fisik Wasit CIII sepakbola PSSI Sumatera Selatan dilihat dari segi daya tahan dalam penelitian ini sebenarnya membentuk distribusi normal.

\section{Wasit CII Tingkat Pengda Daya tahan lari 20 x 150 Meter}

Hasil perhitungan uji normalitas dapat dilihat pada lampiran dan di bawah ini:

Tabel 2

Uji normalitas data Daya tahan wasit CII dengan Uji Shapiro Wilk.

\begin{tabular}{lrrrrrrr}
\hline & \multicolumn{3}{c}{ Kolmogorov-Smirnov(a) } & \multicolumn{3}{c}{ Shapiro-Wilk } \\
\cline { 2 - 7 } Daya tahan wasit CII & Statistic & Df & Sig. & Statistic & df & Sig. \\
\cline { 2 - 8 } & & .292 & 14 & $\begin{array}{r}.00 \\
2\end{array}$ & .808 & 14 & .006 \\
\hline
\end{tabular}

a. Lilliefors Significance Correction

Dari tabel 2, dapat dilihat skor Signifikansi untuk kondisi fisik Wasit CII PSSI Sumatera Selatan dilihat dari segi daya tahan sebesar 0.808. Berdasarkan landasan pengambilan keputusan di atas, Ha diterima. Dengan demikian dapat dinyatakan bahwa data dari kondisi fisik Wasit CII sepakbola PSSI Sumatera Selatan dilihat dari segi daya tahan dalam penelitian ini sebenarnya membentuk distribusi normal.

\section{Wasit CI Tingkat Nasional Daya tahan lari 20 x 150 Meter.} bawah ini:

Hasil perhitungan uji normalitas dapat dilihat pada lampiran dan seperti di 
Tabel 3

Uji normalitas data Daya tahan wasit CIdengan Uji Shapiro Wilk.

\begin{tabular}{llllllll}
\hline & \multicolumn{3}{c}{ Kolmogorov-Smirnov(a) } & \multicolumn{4}{c}{ Shapiro-Wilk } \\
\cline { 2 - 7 } Daya tahan wasit CII & \multicolumn{2}{c}{ Statistic } & Df & Sig. & Statistic & df & Sig. \\
\cline { 2 - 8 } & & .183 & 10 & .200 & .918 & 10 & .341 \\
\hline
\end{tabular}

a. Lilliefors Significance Correction

Dari tabel 3, dapat dilihat skor Signifikansi untuk kondisi fisik Wasit CI PSSI Sumatera Selatan dilihat dari segi daya tahan sebesar 0.918. Berdasarkan landasan pengambilan keputusan di atas, Ha diterima. Dengan demikian dapat dinyatakan bahwa data dari kondisi fisik Wasit CI sepakbola PSSI Sumatera Selatan dilihat dari segi daya tahan dalam penelitian ini sebenarnya membentuk distribusi normal.

\section{Wasit CIII Tingkat Pengcap Wasit CIII dari Segi Kecepatan lari 6 x 40 Meter.} bawah ini:

Hasil perhitungan uji normalitas dapat dilihat pada lampiran dan seperti di

Tabel 4

Uji normalitas data kecepatan wasit CIIIdengan Uji Shapiro Wilk.

\begin{tabular}{llllllll}
\hline & \multicolumn{3}{c}{ Kolmogorov-Smirnov(a) } & \multicolumn{4}{c}{ Shapiro-Wilk } \\
\cline { 2 - 8 } Daya tahan wasit CII & Statistic & Df & Sig. & Statistic & df & Sig. \\
\cline { 2 - 8 } & & .227 & 12 & .090 & .887 & 12 & .109 \\
\hline
\end{tabular}

Dari tabel 4, dapat dilihat skor Signifikansi untuk kondisi fisik Wasit CIII PSSI Sumatera Selatan dilihat dari segi daya tahan sebesar 0.887. Berdasarkan landasan pengambilan keputusan di atas, Ha diterima. Dengan demikian dapat dinyatakan bahwa data dari kondisi fisik Wasit CIII sepakbola PSSI Sumatera Selatan dilihat dari segi kecepatan dalam penelitian ini sebenarnya membentuk distribusi normal.

Wasit CII Tingkat Pengcap Wasit CII dari Segi Kecepatan lari 6 x 40 Meter. bawah ini:

Hasil perhitungan uji normalitas dapat dilihat pada lampiran dan seperti di

Tabel 5

Uji normalitas data kecepatan wasit CIIdengan Uji Shapiro Wilk.

\begin{tabular}{llllllll}
\hline & \multicolumn{3}{c}{ Kolmogorov-Smirnov(a) } & \multicolumn{3}{c}{ Shapiro-Wilk } \\
\cline { 2 - 8 } Daya tahan wasit CII & Statistic & Df & Sig. & Statistic & df & Sig. \\
\cline { 2 - 8 } & & .177 & 14 & .200 & .927 & 14 & .274 \\
\hline a. Lilliefors Significance Correction & & & & & & &
\end{tabular}

Dari tabel 5, dapat dilihat skor Signifikansi untuk kondisi fisik Wasit CII PSSI Sumatera Selatan dilihat dari segi daya tahan sebesar 0.927. Berdasarkan 
landasan pengambilan keputusan di atas, Ha diterima. Dengan demikian dapat dinyatakan bahwa data dari kondisi fisik Wasit CII sepakbola PSSI Sumatera Selatan dilihat dari segi kecepatan dalam penelitian ini sebenarnya membentuk distribusi normal.

\section{Wasit CI Tingkat Pengcap Wasit CI dari Segi Kecepatan lari 6 x 40 Meter.} bawah ini:

Hasil perhitungan uji normalitas dapat dilihat pada lampiran dan seperti di

Tabel 6

Uji normalitas data kecepatan wasit CIdengan Uji Shapiro Wilk.

\begin{tabular}{lrrrrrrr}
\hline & \multicolumn{3}{c}{ Kolmogorov-Smirnov(a) } & \multicolumn{3}{c}{ Shapiro-Wilk } \\
\cline { 2 - 7 } Daya tahan wasit CII & Statistic & Df & Sig. & Statistic & df & Sig. \\
\cline { 2 - 7 } & .310 & 10 & .007 & .761 & 10 & .005 \\
\hline
\end{tabular}

a. Lilliefors Significance Correction

Dari tabel 6, dapat dilihat skor Signifikansi untuk kondisi fisik Wasit CI PSSI Sumatera Selatan dilihat dari segi daya tahan sebesar 0.761. Berdasarkan landasan pengambilan keputusan di atas, Ha diterima. Dengan demikian dapat dinyatakan bahwa data dari kondisi fisik Wasit CI sepakbola PSSI Sumatera Selatan dilihat dari segi kecepatan dalam penelitian ini sebenarnya membentuk distribusi normal.

\section{PEMBAHASAN}

\section{Kondisi Fisik Wasit Sepakbola Pengcap PSSI Sumatera Selatan Dilihat dari Segi Daya Tahan.}

Daya tahan merupakan elemen kondisi fisik yang terpenting, oleh karena itu basis dari elemen-elemen kondisi fisik yang lain. Weineck dalam Safrudin (1999) mengartikan daya tahan sebagai kemampuan tubuh dalam mengatasi kelelahan fisik dan psikis (mental). Tujuan utama dari latihan daya tahan adalah meningkatkan kemampuan kerja jantung disamping meningkatkan kerja paru-paru dan sistem peredaran darah. Secara umum kemampuan daya tahan dibutuhkan dalam semua cabang olahraga yang membutuhkan gerak fisik.

Selanjutnya Arsil (1989) menjelaskan bahwa daya tahan dalam permainan sepakbola merupakan kesanggupan tubuh untuk melakukan aktivitas selama berlangsungnya permainan. Menjadi seorang wasit sepakbola, daya tahan sangat dibutuhkan, hal ini dikarenakan seorang wasit sepakbola hendaklah aktif dalam lapangan selama permainan berlangsung. Darwis (1999) mengemukakan,"Daya tahan adalah kemampuan organisme tubuh untuk mengatasi kelelahan yang timbul setelah melakukan aktifitas tubuh berolahraga dalam waktu lama".

Berdasarkan uraian dari analisis data di atas dapat dinyatakan bahwa daya tahan wasit CIII PSSI Sumatera Selatan berada pada kategori cukup dengan ratarata 13, ini artinya bahwa wasit CIII hanya mampu melakukan 7 kali pengulangan dalam melakukan lari satu lintasan lapangan. Wasit CII Tingkat Pengda berada pada kategori kurang dengan rata-rata 10, ini artinya bahwa wasit CII hanya mampu melakukan 5 kali pengulangan dalam melakukan lari satu lintasan lapangan. Selanjutnya wasit CI Nasional berada pada kategori baik dengan ratarata 15, ini artinya bahwa wasit CI hanya mampu melakukan 5 kali pengulangan 
dalam melakukan lari satu lintasan lapangan. Dari gambaran di atas dapat disimpulkan kemampuan kondisi fisik wasit sepakbola PSSI Sumatera Selatan berdasarkan tes daya tahan berada pada taraf baik.

\section{Kondisi Fisik Wasit Sepakbola PSSI Sumatera Selatan Dilihat dari Segi Kecepatan.}

Jonath dan krempel dalam Syafruddin (1999) mengatakan "kecepatan dibatasi oleh faktor-faktor seperti ; Kekuatan, Kecepatan dan koordinasi. Pada seorang Wasit sepakbola yang memiliki kecepatan yang baik akan mampu berada saat terjadinya pelanggaran atau kejadian-kejadian dalam pertandingan sepakbola, tidak hanya mengambilkan keputusan yang adil pada pasal 12 peraturan umum pertandingan sepakbola.

Dalam kontek ini wasit mencakup dari semua komponen yang membatasi faktor-faktor yang kecepatan.Tidak hanya seorang wasit cepat, tetapi juga harus ada keseimbangan antara komponen-komponen yang tercakup didalamnya. Dari hasil pengukuran diatas didapat bahwa wasit CIII dilihat dari segi kecepatan berada pada ketegori baik sekali dengan rata-rata 5, selanjutnya wasit CII dilihat dari segi kecepatan berada pada ketegori baik dengan rata-rata 4, dan wasit CI dilihat dari segi kecepatan berada pada ketegori baik sekali dengan rata-rata 5.Kesimpulan yang bisa diambil bahwa kondisi fisik wasit sepakbola PSSI Sumatera Selatan berada pada kategori baik sekali.

\section{SIMPULAN}

Berdasarkan penelitian di atas, maka dapat disimpulkan bahwa kondisi fisik wasit PSSI Sumatera Selatan berada pada taraf baik sekali dalam hal daya tahan dan kecepatan.

\section{DAFTAR PUSTAKA}

Arsil .(1989). Pentingnya Latihan Kondisi Fisik Untuk Meningkatkan Prestasi Pemain Sepakbola Makalah. Padang: FPOK IKIP

Arsil .(1999). Pembinaan Kondisi Fisik. Padang: Fakultas Ilmu Keolahragaan Universitas Negeri Padang (UNP)

Darwis, R. (1999). Sepakbola. Universitas Negeri Padang

Hos, F. (1989). Teori Gerak. Padang ; FPOK. IKIP

Prihastono, A. (1999). Pembinaan Kondisi Fisik Karate, Solo; CV Aneka

Sarumpeat, A. (1986). Dasar-dasar Pembinaan Gulat. Bandung: Alphabeta

Syafruddin, (1999).Dasar-dasar Kepelatihan Olahraga.Padang ; FIK-UNP DIP Proyek Universitas Negeri Padang. 